\begin{tabular}{cccc}
\hline Bentham open & The Open Petroleum Engineering \\
CrossMark & Journal \\
DOI: $10.2174 / 1874834101609010324$ & Content list available at: www.benthamopen.com/TOPEJ/
\end{tabular}

\title{
RETRACTION
}

\section{Retraction Notice: Composite Advanced Detection for Coal Seam Thickness in Coal Roadway}

Wang Bo ${ }^{1,2}$, Zhang Xiayang ${ }^{1,2}$, Liu Shengdong ${ }^{1,2, *}$, Lu Tuo ${ }^{1,2}$ and Chen Mulan ${ }^{1}$

${ }^{I}$ State Key Laboratory of Deep Geomechanics \& Underground Engineering, China University of Mining \& Technology, Xuzhou 221008, China

${ }^{2}$ School of Resources and Earth Science, China University of Mining \& Technology, Xuzhou 221008, China

\section{RETRACTION}

The Publisher and Editor have retracted this article [1] in accordance with good ethical practices. After thorough investigations we believe that the peer review process was compromised. The article was published online on 31-03-2015.

\section{REFERENCE}

[1] W. Bo, Z. Xiayang, L. Shengdong, L. Tuo, and C. Mulan, "Composite advanced detection for coal seam thickness in coal roadway", Open Pet. Eng. J., vol. 8, pp. 153-157, 2015.

(C) Bo et al.; Licensee Bentham Open.

This is an open access article licensed under the terms of the Creative Commons Attribution-Non-Commercial 4.0 International Public License (CC BY-NC 4.0) (https://creativecommons.org/licenses/by-nc/4.0/legalcode), which permits unrestricted, non-commercial use, distribution and reproduction in any medium, provided the work is properly cited.

\footnotetext{
* Address correspondence to this author at the University Road, Xuzhou, China. Postcard: 221008; Tel: +86 51683995678; E-mail: wbsyes@126.com
} 